\title{
Imagens e Imaginários: do moderno ao pós-moderno ${ }^{1}$
}

\author{
Maria Beatriz Furtado Rahde ${ }^{2}$ \\ PUCRS \\ frahde@portoweb.com.br \\ Flávio Vinicius Cauduro3 \\ PUCRS \\ flaviocauduro@yahoo.com
}

\begin{abstract}
Resumo: As manifestações visuais do contemporâneo fazem parte da mídia, diariamente transformadas, como parte dos mitos do imaginário cultural e social. Procuramos estabelecer algumas relações entre a cultura, o imaginário e as imagens da comunicação, do cinema, e das histórias em quadrinhos, e seus reflexos no contemporâneo. Enfatizamos também as visualidades que permearam a modernidade e que apresentam outros direcionamentos no imaginário da pós-modernidade.
\end{abstract}

Palavras-chave: Imagem - Imaginário - Moderno - Pós-moderno Retórica visual

\begin{abstract}
The contemporary, postmodern visual manifestations we observe in the media, are in continuous transformation, for they are an important part of the myths of both the cultural and the social imaginary. Thus, in this article we try to establish some relationships (differences) between images produced by the cultural imaginary in films, in comics and other visual manifestations, during modernity as well as in the postmodern era.
\end{abstract}

Key-words: Image - Imaginary - Modern - Postmodern - Visual rhetoric.

\footnotetext{
${ }^{1}$ Trabalho realizado com apoio do CNPq durante o nosso Projeto Universal Algumas Características das Imagens Contemporânea, na etapa 2005-2007.- Apoio CNPq/Pibic/Pucrs ${ }^{2}$ Doutora em Educação: Pontifícia Universidade Católica do Rio Grande do Sul. Professora Titular do PPGCom/ PUCRS. LP: Tecnologias do imaginário, ênfase em Comunicação Visual. Artigos publicados em revistas acadêmicas: Brasil, França, Espanha. Pesquisadora PIBIC/PUCRS/CNPq.

3 PhD in Graphic Comunication: Reading University. Professor Adjunto do PPGCom/Pucrs. LP: Tecnologias do imaginário, ênfase em Comunicação Visual Pesquisador CNPq-1d.
} 
Résumé: Les manifestations visuelles de la contemporaneité sont partie de la midia, transformés touts les jours et faire partie, aussi, des mythes de l'imaginaire cultural et social. Cet article établie quelques relations entre la culture, limaginaire et les images de la communication du cinéma et des bandes dessinées comme réflexes de la contemporaneité. Remarque, aussi, les visualités au milieu de la modernité, qui présente autres chémins dans l'imaginaire de la postmodernité.

Mots-clés: Image - Imaginaire - Moderne - Postmoderne - Rétiorique visuel

Resumen: Las manifestaciónes visuales del contemporáneo hacen parte de los medios transformadas diariamente, como parte de los mitos del imaginario cultural y social. Intentamos estabelecer algunas relaciones entre la cultura y el imaginario y las imagenes de la comunicación del cine, de las historietas y sus reflexos en el contemporáneo. Presenta tambien las visualidades qui han permeado la modernidad y qui presentan otros direccionamientos en el imaginario de la postmodernidad.

Pallavras-llave: Imagen - Imaginario - Moderno - Postmoderno Retorica visual.

\section{Introdução}

Enquanto na modernidade as artes visuais representavam a ruptura com o passado, buscando o novo e, muitas vezes o racional, no contemporâneo pósmoderno, as imagens tendem à indefinição, à indeterminação, questionando paradigmas que sustentavam a superioridade da aura e da cultura artísticas modernas. A ambigüidade ou a multiplicidade de significados se manifestam na arte do contemporâneo, com tendências ao cultivo da polissemia. A "aceitação desse estado, não é, na realidade, senão o reconhecimento do aspecto complexo, polissêmico" (Maffesoli, 2001, p.80-81), do sujeito atual. 
Se os significados das obras auráticas da modernidade tendiam ao absoluto, na contemporaneidade pós-moderna manifesta-se um jogo de interpretações sem significados estáveis.

A arte da modernidade segue certas regras ou cânones os quais conferem ou não - a sua legitimidade, principalmente por críticos, envolvendo-a no que Aumont (1995) denomina aura artística, uma espécie de metáfora ao halo, à luminosidade, ao incomum. Podemos verificar, através da História da Arte, que essa aura era uma condição imprescindível para a arte, com a originalidade, o inédito, constatando que "em quase todas as sociedades que conheceram um desenvolvimento artístico, a arte é dotada de um valor especial que confere a suas produções uma natureza fora do comum, um prestígio particular, uma aura" (Aumont, 1995, p. 300).

Os movimentos modernistas, que tiveram seu início no Expressionismo, não fugiam desses preceitos e a idéia da novidade, da originalidade, desse fora do comum a que Aumont refere era uma constante. Praticamente todos os movimentos que se seguiram ao Expressionismo possuíam essa aura, denotando superioridade atestada pelo artista e pelos críticos que falavam de "talento" ou genialidade do criador.

Pensemos por exemplo no Surrealismo. Vinculado à esfera do sonho, intimamente relacionando atividades oniropoiéticas com atividades mitopoiéticas, o Surrealismo, como estilo moderno, foi a transcrição do pensamento, sem nenhum tipo de controle da razão, de acordo com André Breton, no seu Manifesto de 1924. Reflete, muitas vezes, imagens coletivas, utilizando-se de imagens mitológicas como impulso poético.

O Surrealismo da primeira metade do século XX será o resultado natural e reconhecido do Simbolismo. Este 'sexto sentido', que no século das Luzes revelou ingenuamente a estética, desabrochou numa filosofia de um universo completamente diferente do pensamento humano... (Durand, 1998, p.29-30).

No Manifesto Surrealista, Breton entende que o inconsciente é o lugar da imaginação e a arte Surrealista torna-se uma justaposição de manifestações plásticas, poéticas, numa ordem psicológica e inconsciente. As pinturas oníricas de Dali são um 
exemplo deste imaginário desprovido de algumas tendências positivistas da modernidade.

Bachelard refere que a imaginação geralmente é indicada como a capacidade de formar imagens. Recusando esta idéia, o autor define imaginação como

...a faculdade de "deformar" as imagens fornecidas pela percepção, é sobretudo a faculdade de libertar-nos das imagens primeiras, de "mudar" as imagens... Se uma imagem "presente" não faz pensar uma imagem "ausente", se uma imagem ocasional não determina uma prodigalidade de imagens aberrantes, uma explosão de imagens, não há imaginação. (Bachelard, 1990, p.1)

Essa é uma reflexão que descreve a arte moderna e também o surreal, transcrevendo imagens como produtos do imaginário e situadas na esfera do sonho, do inconsciente, do espontâneo ou do impulsivo, expressando processos visuais da arte/comunicação do pensamento e da criação humanas.

Com toda a sua expressividade, o Surrealismo foi, também, um movimento aurático, imaginativo, arrojado, novo, que atingiu não só as artes plásticas, mas também participou dos meios de comunicação, por meio de cenários oníricos, criados por Salvador Dali, em 1945 para a produção cinematográfica de Alfred Hitchcock, Spellbound.

Podemos perceber que a simbologia perpassa nossos imaginários e com referência ao símbolo, o psicólogo Philippe Malrieu (1996, p. 128) refere que ele "representa uma forma por meio de outra. É uma espécie de retrato, que permite... distinguir um objeto dos outros, mas de uma forma diferente da palavra..." Pode-se dizer que as representações simbólicas são interpretadas por descoberta. Portanto, o ato de imaginar e de criar poderá ser uma projeção na recuperação de passados recentes ou remotos, sem o intuito de reproduzí-los, mas sim de transformá-los frente ao imaginário coletivo de um grupo, de uma cultura, de uma sociedade, como meio de comunicação artístico/visual.

Existindo como histórias representativas visuais desde a Antigüidade, as histórias em quadrinhos de heróis simbólicos e modernos surgiram nesse período, revolucionando a comunicação visual de massa e sendo vistas por muitos sociólogos e críticos da época como um gênero visual híbrido e vulgar mas que em nossos dias, é 
considerado como uma manifestação legítima do imaginário popular, de mesmo valor que as concepções iconográficas altamente elaboradas da cultura oficial de elite.

\section{Imaginários míticos modernos e contemporâneos}

Na contemporaneidade, nos mais diversos meios de comunicação, novas culturas da imagem se sobressaem, vêm explorando os jornais e revistas, o cinema e os quadrinhos, com imagens midiáticas para a massa, "jogando com uma vasta gama de emoções, sentimentos e idéias. A cultura da mídia é industrial; organiza-se com base no modelo de produção de massa [...] (J Kellner, 2001, p. 9). É dessa forma que nas culturas midiáticas da atualidade, os sujeitos recebem um novo fluxo de imagens como entretenimento e informação, uma vez que essa cultura se apresenta como dominante, diminuindo processos culturais de elite (Kellner, 2001). Ainda refere o autor que a cultura social da pós-modernidade vem conduzindo a sociedade e a cultura para mudanças significativas, num estado de efervescência, que estão desafiando teóricos para explicar o ecletismo, as bricolagens, os hibridismos.

As histórias em quadrinhos e a arte cinematográfica têm contribuído de maneira muito presente, face às preferências do receptor dessas imagens, e os estudos culturais podem tornar mais claras as idéias dessas alterações, estimulando imaginários míticos,

Para melhor caracterizar as mudanças que estão ocorrendo nos paradigmas da visualidade e das culturas pós-modernas é preciso verificar rupturas, desestruturas visuais e textuais, novas tecnologias, hibridações, que as artes da comunicação visual da contemporaneidade estão vivenciando.

Distanciando-se da imitação naturalista, as imagens passaram por releituras que, apesar do aparente realismo, se converteram em signos provocativos, signos de signos, imaginários de imaginários, satirizando a procura de signos de objetividade e os estereótipos, no contexto pós-moderno, como já previa a recursividade da semiótica de Peirce.

Os processos tanto artísticos como de comunicação dos mitos populares aparecem modificados na visualidade do imaginário pós-moderno, principalmente nas artes visuais, por volta dos anos sessenta. O desenvolvimento da indústria do 
consumo mitificou elementos ou pessoas, de forma acelerada. O artista plástico Andy Warhol (1930-1987) entregou-se a um trabalho pictórico encadeado e relacionado à produção industrial, seja de objetos de consumo, seja da indústria cinematográfica, e que podemos considerar como um precursor da visualidade pós-moderna. As latas de sopa Campbell, os astros e atrizes do cinema, típicos objets truvés da cultura de massa, ou ready mades da produção industrial imortalizados por este artista, assim como as histórias em quadrinhos, reproduzidas à mesma época por Roy Lichtenstein, elevam-se à categoria de obras auráticas, mitificadas, quando ocupam grandes telas nos principais museus do mundo: Marilyn Monroe, Elvis Presley, Mao Tse Tsung, e garrafas de Coca-Cola são os novos mitos de uma pós-modernidade emergente, que Warhol perpetuou a partir do período da Pop-Art anglosaxonica (Thomas, 1994). Com Robert Rauschenberg, considerado o mais transgressivo dos criadores de imagens pós-modernas, temos sua série Tracer, apresentando, entre diversas colagens, a imagem de "Vênus no Banho" de Rubens, através da qual foi comunicada a experiência sensível como base cultural PARA novas formas de conhecimento. A metafísica, que justificava a ética aristotélica, como forma superior de vida, dá lugar à ironia no contemporâneo pós-moderno, em que o imaginário cultural se manifesta nas fantasias ou nas manifestações mitopoiéticas.

Referindo que há uma íntima proximidade entre a cultura e o imaginário, Maffesoli (2001) confirma que esta nova cultura, que vem perpassando a contemporaneidade, é coletiva, vinculando-se aos grupos humanos e servindo de alimento aos sonhos construídos por estes grupos, que se identificam com os novos mitos do cotidiano. A imagem "instante eterno, que, em um relâmpago exprime o cosmo em sua totalidade" (Maffesoli, 1995, p. 138) tornou-se eternizada neste momento, pela criação e pela imaginação do desenhista de quadrinhos, agora aliando conhecimento tecnológico ao sentimento artístico. Produzir imagens "irreais" ou “imateriais" diz Luz (1993) tornou-se, pois, uma instância de criação, a serviço da imaginação estética, da ciência ou do lúdico.

Pondera Ruiz que o imaginário

corresponde ao aspecto insondável do ser humano, em que se produz, além de todos os condicionamentos psíquicos e sociais, o elemento criativo; ele constitui o 'sem- fundo' inescrutável da pessoa humana, que possibilita a imaginação e também a 
racionalidade como dimensões próprias do humano. (Ruiz, 2003, p. 32)

Em meio a essas mudanças de ordem cultural e tecnológica, o imaginário mitico resistiu ao pluralismo e transformaram-se os sonhos das muitas culturas quase que numa só, frente à globaliação das artes populares na comunicação contemporânea.

As tecnologias do imaginário, como a televisão, o cinema, os quadrinhos, as inúmeras possibilidades de novas visualidades imagísticas computacionais, que desenvolveram-se rapidamente nas últimas décadas, vêm estimulando a imaginação mesmo na aparente racionalidade destes meios de comunicação partilhados pela cultura. Os mitos, então, poderiam ser chamados de uma cosmogonia destas culturas, assim como o sonho, a fantasia, a imaginação.

Evidente que o imaginário coletivo repercute no indivíduo de maneira particular. Cada sujeito está apto a ler o imaginário com certa autonomia. Porém, quando se examina o problema com atenção... vê-se que o imaginário de um indivíduo é muito pouco individual, mas sobretudo grupal, comunitário, tribal, partilhado. (Maffesoli, 2001, p. 80)

Se a imagem do herói mítico da modernidade, ser único e solitário, foi marcada muitas vezes pela objetividade e o positivismo, pela moralidade, pela busca da emancipação, por uma estética visual autônoma, em oposição às tiranias políticosociais, na pós-modernidade diversos movimentos contraculturais exploraram os domínios individualistas modernos "numa profunda mudança na estrutura do sentimento" (Harvey, 1992, p. 45), de fragmentações e efemeridades , em que a utopia pela busca de mundos melhores , preconizados pela modernidade, dão lugar a um status pós-utópico e no qual o imaginário atua de forma coletiva, grupal, não mais pregando o individualismo heróico..

O herói pós-moderno, como as personagens das histórias em quadrinhos ou as do cinema contemporâneos, é pleno de incertezas, e não mais o ser invencível do bem e da verdade, pois é marcado por desconstruções visuais e textuais, demonstrando a sua fraqueza, suas incertezas e sensibilidade frente às lutas cotidianas. O herói pós-moderno é muitas vezes o anti-herói, tentando conciliar seu mundo imaginário, idílico, mítico, com a luta pela sobrevivência em terrenos hostis. 
O enriquecimento do imaginário nos mitos pós-modernos é cada vez mais evidente e, de certa forma, repete a tradição da cosmogonia mítica. A atividade mitopoiética permanece, alimentada pelas novas tecnologias, em que os jogos E intervenções do acaso são mais evidentes do que os projetos acabados e refinados da modernidade.

Um bom número de exemplos dessa mudança ainda podem ser encontrados nos meios de comunicação, tais como as imagens dos heróis das novelas televisivas, os personagens heróicos do cinema contemporâneo. Basta ver o filme Uma mente brilhante (2001), em que o "herói” da bem engendrada trama é um sábio esquizofrênico, vivendo num mundo imaginário, em que sonhos e realidades se mesclam, e com o qual o espectador se identifica, pois reconhece como seu este mundo criado pelo personagem, pleno de incertezas, receios, vitórias, frustrações. Mas o personagem é e representa a imagem do herói desconstruído, híbrido, mítico, frustrado muitas vezes, levando o espectador a identificações, reflexões e projeções instáveis do próprio eu.

O espetáculo das telenovelas, a nova arte dos séculos XX e XXI, é alimentada por fenômenos do contemporâneo pós-moderno, que evocam, como já refere Maffesoli os "mundos imaginais" atuantes sobre o telespectador. Além de ditarem a moda, a música, a atitude certa e/ou incerta dos atores sobre os espectadores, eles conduzem o sujeito a questionamentos que destroem padrões maniqueístas do bem e do mal, do certo/ errado em nome das necessidades individuais de cada personagem, de condutas que foram consideradas ilícitas durante a modernidade e que agora são aceitas em nome de outros valores, de misérias ou de solidão humanas.

Para melhor compreender as correspondências míticas desta nova forma cultural de comunicação, amalgamada às visualidades do contemporâneo, diz Malrieu (1996) que é preciso não ignorar as muitas e múltiplas angústias humanas, sejam elas a busca do ser ideal, a rejeição da solidão, da morte. Será no imaginário mítico que a pessoa encontrará o refúgio e a tranqüilidade de um mundo novo e apaziguado, numa identificação do sujeito espectador com a trama desenrolada no espetáculo televisivo ou cinematográfico. A telenovela tem sido a harmonia estética, o retiro e o amparo de milhares de espectadores, quando trazem - e quase sempre o 
fazem - imagens e questões do contemporâneo para serem comunicadas de forma fantástica, espetacularizada, envolvendo pessoas de todas as camadas sociais.

O processo de mitização na sociedade tribal está muito bem fundamentado nas aspirações coletivo/individuais do sujeito do contemporâneo: é o que Eco (1970) chamou de "símbolos do status". Segundo processos mitopoiéticos, um novo tipo de automóvel, um DVD que já supera o vídeocassete, o filme digitalizado, os sons remasterizados digitalmente passam a habitar o imaginário humano como objetos imprescindíveis à própria visão de sobrevivência. Possuir e/ou usufruir de tais objetos são características do "ser herói" hoje. Se o bisonte primitivo desenhado nas paredes das cavernas representava a posse de sua imagem pelo ser criador, diz Eco, hoje um revolucionário automóvel, cuja imagem é apresentada um sem número de vezes nas propagandas de televisão, com designs tentadores e de poderosa beleza estética, não está muito distante da imagem do bisonte, do mesmo sentimento de posse que nutre o imaginário do homem contemporâneo.

O objeto é a situação social e, ao mesmo tempo, o seu signo: conseqüentemente, não constitui apenas um fim concreto a ser perseguido, mas o símbolo ritual, a imagem mítica em que se condensam as aspirações e os desejos. É a projeção do que queremos ser. (Eco, 1970, p. 243)

É o nosso conhecido objeto de desejo. Essa necessidade atrativa pelo objeto, participar do e com o objeto, como num ato quase cerimonial, torna-se uma nova construção mítica do imaginário tecnológico do homem contemporâneo. Maffesoli (1995) reforça esta idéia quando refere sobre a comunhão entre o homem pósmoderno e suas posses, ao tocá-las quase em reverência, numa analogia às velhas superstições, como um retorno ao sagrado, demonstram que todo o ato ritual é participativo, revelador e construtor de novos imaginários míticos.

Questionando-nos sobre as imagens que perpassam o imaginário na construção dos mitos da contemporaneidade, acreditamos que são muitos os fatores de influência e que apenas podemos refletir que, no labirinto pós-moderno, a hibridação das idéias, das sensações, das percepções, dos anseios, das muitas imagens amalgamadas no sensorial e no conhecimento influenciaram os grupos num conjunto de crenças pré-existentes, como uma rede de muitas tramas. O sujeito pósmoderno parece estabelecer relações entre as coisas que o cercam e que invadem o 
seu imaginário de forma modificada para reconstruir ações ancestrais com outros significados.

É o irreal que comanda o realismo da imaginação, já dizia Bachelard e a imagem que habita o mundo imaginário numa ligação íntima, amalgamando-o, fornece "os vínculos, relaciona todos os elementos do dado mundano entre si" (Maffesoli, 1995, p. 115).

$\mathrm{Na}$ verdade ao resgatar as idéias de Bachelard, Maffesoli imprime a devida importância ao que denomina mundo imaginal na construção da realidade. Acreditamos que a vida real não está em compartimento separado da vida imaginária e como já referia Hillman, citado por Avens (1993), o reconhecer da "realidade" do "inconsciente", nada mais é do que um re-conhecimento da profundidade e da totalidade da mente humana. Portanto, não somos seres apenas reais, objetivos: somos um amálgama de um imaginário racional/surreal que constrói e convive com nosso cotidiano cultural.

Se na modernidade passamos pela experiência de manifestações artísticas, algumas vezes valorizando a racionalidade, na condição pós-moderna, como podemos classificar a contemporaneidade vivenciada, estamos observando o fenômeno da busca da mística (Weiler, 1998). Entendemos aqui a mística como uma atitude mental baseada tanto na intuição e no sentimento, como no conhecimento racional. É assim, diz Lyotard (1994), que a condição pós-moderna "designa o estado da cultura depois das transformações que afetaram as regras do jogo da ciência, da literatura e das artes a partir do século XIX” (p. 9). Essas transformações relacionamse também com a crise dos grandes relatos: o valor da verdade era considerado correto se estivesse inscrito na perspectiva de uma unanimidade possível dos espíritos racionais, diz ainda Lyotard, e prossegue:

... este era o relato das Luzes, onde o herói do saber trabalha para para uma boa finalidade épica-política, a paz universal. Neste caso vê-se que, ao legitimar o saber por meio de um metarrelato que implica uma filosofia da história, questiona-se a validez das instituições que regem o laço social: também elas exigem ser legitimadas... Tem-se por "pós-moderna", a incredulidade com respeito aos metarrelatos... [pois] não formamos combinações lingüísticas... estáveis... é a heterogeneidade dos elementos. (Lyotard, 1994, p.10) 
A ponderação de Lyotard sobre a fragmentação e a instabilidade da linguagem na condição pós-moderna, esta visão de intuição sobre as grandes verdades instituídas PELO modernismo, fortifica o imaginário dos grupos, na construção das imagens, das artes, dos objetos míticos, que vêm se manifestando na contemporaneidade.

É assim que a construção das muitas visualidades, da produção, dos objetos que cercam o homem pós-moderno, muitas vezes são efêmeras. Grupos musicais são mitificados momentaneamente, desaparecendo da mídia em pouco tempo, assim como do imaginário coletivo; novelas de televisão permanecem no ar ditando modelos aparentemente imutáveis, mas estas imagens se fragmentam, quando novas imagens de novas novelas entram em cartaz, invadindo o imaginário dos grupos, e os seres mitificados anteriormente cedem lugar a novas mitificações e assim sucessivamente. Desapareceu a legitimação das grandes narrativas neste contemporâneo de narrativas transitórias, constituídas de pequenas histórias sem a visão de um princípio, meio, fim. A continuação descontínua, os jogos artísticos, oscilam entre uma pequena história e um jogo do acaso, que visam angariar audiência para a televisão, vender obras de arte, apresentar instalações em galerias pouco convencionais, vender produtos, prender a atenção do consumidor, promover a persuasão. E é neste jogo de acasos, que controvérsias, característica também do pós-moderno, acontecem em pleno século XXI.

É assim que as imagens do contemporâneo são imagens de participação do espectador, não mais a arte aurática, individual e hermética do artista solitário. A arte hoje é uma arte interativa, produto de um imaginário social e cultural, que muitas vezes ironiza, de maneira sutil, as manifestações artísticas da alta cultura da modernidade, mas sem exclusão do imaginário mítico.

Mas foi na modernidade recente, como já referimos, que apareceram os consagrados heróis das histórias em quadrinhos, novo produto da comunicação visual de massa, estimulando imaginários culturais e sociais, e, por isso mesmo, os anos 30 foi $\mathrm{O}$ período denominado como a Idade de Ouro dos quadrinhos, quando surgiram: Tarzan (1929), Buck Rogers (1929), Dick Tracy (1931), Flash Gordon (1933/4), Mandrake (1934), Fantasma (1936), Superman (1938), Batman (1939). 
O sucesso dessas personagens foi instantâneo e suas tiras diárias E páginas dominicais distribuídas pelo Mc Clure Newspaper Syndicate alcançaram uma circulação de 20.000.000 de exemplares à época, em apenas dois anos de veiculação. (Moya, 1970).

Diante dessas manifestações culturais quadrinizadas, também incluímos nessas reflexões o cinema do contemporâneo, pois os filmes, que têm resgatado temáticas de histórias em quadrinhos, de mais de setenta anos de existência, permanecem elevando o sucesso e a renovação da mídia quadrinizada. Esses resgates de roteiro merecem análise, como textos visuais, que reinterpretam heróis do passado, num processo de delineamentos culturais ideológicos.

Como condição inclusiva de diversas épocas, o contemporâneo não mais é a grande narrativa da modernidade, mas se constitui de breves desafios ao existente, transformando culturas elitizadas em culturas populares.

\section{Imaginários culturais quadrinizados e cinematográficos em Batman}

Dentre as tantas personagens da cultura de massa procuraremos analisar Batman, o herói nascido na modernidade e que vem alcançando sucesso no contemporâneo, tanto nos quadrinhos, como na indústria cinematográfica.

Criado pelo desenhista Bob Kane e o escritor Bill Finger, Kane recebeu maiores créditos, apesar de seus esforços para dividí-los com seu roteirista. Aficcionado pelas histórias de vampiros, o imaginário de Kane concebeu um herói de traje negro, ligando-o ao tema dos morcegos. Diferentemente de super-heróis, Batman não possui super poderes mas compensa essa deficiência com a inteligência que o caracteriza, buscando em aparatos, como a Bat-corda, o Bat-móvel , todos concebidos na Bat-caverna. Com seu poder financeiro e no desenvolvimento da força física, o herói passou a dedicar sua vida para combater o crime com a tecnologia de ponta, que lhe fornecia suas superarmas e seus superequipamentos.

A década de 30 foi o período de grande produção literária do romance norte-americano, em que o surgimento do best-seller passou a se difundir As histórias em quadrinhos dessa época poderiam ser definidas como uma literatura paralela, intimamente vinculadas aos movimentos culturais dos anos 30, além de sua 
ligação íntima com os movimentos sóciais, políticos, filosóficos e artísticos, que floresciam a cada momento nesse período da Idade de Ouro, que os Estados Unidos da América vivenciavam. Afirma Eco (1970), que essa literatura midiática e também paralela obteve grande eficácia de convicção junto ao sujeito receptor, apenas comparável aos mitos, tendo sido, também por meio dela, a construção de imaginários de alta significação psicológica.

Permanecendo nos tempos subseqüentes de sua criação, as histórias de Batman passaram por alterações, de maior ou de menor porte, conforme a cultura midiática e tecnológica da cada época. Alguns elementos, como sua personalidade, sofreram mudanças drásticas; outros, como a morte de seus pais e sua busca pela justiça, permaneceram.Uma constante nas diversas versões do Homem-Morcego demonstra que Batman é o alter-ego de Bruce Wayne, a verdadeira identidade do herói, um multi-milionário que é proprietário das Indústrias Wayne, um filantropo, que optou por combater o crime em Gotham City, após o assassinato de seus pais.

Dessa forma, o leitor americano e os leitores dos demais países para onde a série foi difundida quase que instantaneamente participavam com intensidade desse imaginário onírico e mítico, "como se participa de fatos que tocam de perto a coletividade" (Eco, 1970, p.224). Os mitos da época giravam em torno da justiça e da ordem, dos heróis legendários, numa visão cultural midiática, ainda aficcionada pela cultura de elite, de acordo com os cânones da modernidade.

Analisando esses aspectos da estrutura do herói verifica-se que a sensação de imaginar, de sonhar, de crer no irreal foi, é e tem sido uma necessidade cultural dos povos, desde a Antiguidade. Basta lembrar os gregos com os seus deuses olímpicos.

Na época de sua criação, maio de 1939, os Estados Unidos estavam num período imediatamente anterior à eclosão da $2^{\mathrm{a}}$ Grande Guerra Mundial e a necessidade de heróis, desenvolvia imaginários idealizados para a salvação da coletividade como o capitão américa.

Batman também apareceu em outros meios, alem dos jornais e revistas especializados em quadrinhos. Na televisão, entre 1960-1968, um seriado estrelou Adam West como ao personagem central e Burt Ward como Robin, que já havia sido 
incluído nas histórias nos anos 40. O seriado televisivo era mais humorístico, com onomatopéias gráficas entre as cenas reais e outros recursos visuais possibilitados pela hibridação fotografia/desenho.

Frank Miller foi o responsável pela renovação quase completa da personagem, quando, nos anos 8o, idealizou a mini-série Batman: Ano Um, que deu origem à nova série $O$ Cavaleiro das Trevas, uma história sombria, repleta de situações conflitantes entre Batman e seu contexto sociocultural, permeada por uma iconografia quase expressionista, com desenho a pena e pincel, manchas escuras, que contrastam vigorosamente com a estrutura gráfica.

A personalidade de Bruce Wayne passou a ser repleta de conflitos entre o herói e seu alter-ego, Bruce Wayne, conforme a complexidade que o contemporâneo vivencia. Batman foi e tem sido apresentado com uma personalidade forte, COMPLEXA e sombria. Lutas internas, questionamentos, passam a fazer parte de seu mundo, no mesmo teor dos conflitos globais da cultura, da sociedade, do político do final do séculos XX e início desse século XXI. As mudanças tecnológicas ocorridas nas últimas décadas estão presentes, também, no seu universo de Justiceiro Mascarado. É de se considerar, nesse contexto, que os quadrinhos estão sofrendo alterações, tanto quanto as alterações do contemporâneo. As imagens do herói, do seu ambiente imaginário, Gotham City, hoje, passaram por uma barroquisação textual e iconográfica, que vai ao encontro das referências de Maffesoli, (1996,p.195) quando refere que hoje, "o urbanismo barroco recorre à sensação (ambiente), procede por sedução (aparência), dispõe efeitos (acontecimento)”.

Essas histórias emblemáticas e cultuadas, não só por leitores aficcionados da personagem de Batman, mas também por cineastas contemporâneos de significativa projeção, como Tim Burton, obtiveram, quando do resgate das histórias do herói em 1989, uma das maiores bilheterias da atualidade. Foi assim que iniciou a fase contemporânea com o filme Batman, quando de seu retorno às telas do cinema, num processo midiático quase sem precedentes.

Em 1992 o mesmo Tim Burton lançou Batman Returns e, em 1995 e 1997, o respeitado Joel Schumacher lançou Batman Forever e Batman \& Robin, respectivamente. 
2005 foi a vez do diretor Christopher Nolan apresentar, com sucesso de bilheteria também, Batman Begins, no qual a metáfora da caverna e dos morcegos é enfatizada através de uma maior expressividade de complexos e negros mistérios. Para 2008, já está prevista a produção cinematográfica de The Dark Night, que deverá ser a continuação de Batman Begins.

A imagem simbólica do herói, o imaginário mítico do seu entorno, criados pela cultura de massa, atestam seu retorno como "o retorno cíclico que acentua o destino, tudo coisas que fazem da existência, uma seqüência de instantes eternos” (Maffesoli, 2001, p.12).

Batman é a visão utópica do iconográfico social, industrial, cultural e contemporâneo. Na realidade, ao referir sobre o nosso contemporâneo vivenciado, Maffesoli ainda enfatiza que "é uma [...] utopia que encontramos naquilo a que podemos chamar o mundo 'imaginal' pós-moderno, ou seja um mundo em que a imagem, sob suas diversas modulações, é o elemento essencial do elo social" (2001, p.67).

O imaginário e o real se aproximam, diz Morin (1989) pois a realidade alimenta-se do imaginário. De fato o autor ainda acentua que

O mesmo movimento que aproxima o imaginário do real aproxima o real do imaginário. Em outras palavras: a vida da alma se amplia, se enriquece, se hipertrofia mesmo, no interior da idividualidade [...] A alma é precisamente o lugar de simbiose no qual imaginário e real se confundem e se alimentam um do outro [...]. (Morin, 1989, p. 11)

Esses filmes de Batman dos últimos tempos, têm apresentado características do filme noir dos anos 40, comprovando, também a inclusão e o resgate de obras da cultura midiática do movimento modernista, não excluíndo idéias que possam enriquecer o imaginário sociocultural, uma das características dos movimentos contemporâneos.

Diz-se que o suporte contemporâneo está cada vez mais fragmentado, descentrado e contraditório, o que transparece e caracteriza muito das representações gráfico-visuais atuais. Mesmo assim aquelas ditas modernistas permanecem presentes, mostrando que seus valores ainda resistem à pósmodernização. São opções que não apresenta nenhuma novidade para os antigos, mas que o cultivo da diferença garante nas manifestações visuais de hoje. 
Para auxiliar o leitor a identificar as características e diferenças conceituais de cada uma das condições de representação, a moderna e a pós-moderna, entre as quais a preferência do sujeito contemporâneo oscila, elaboramos a tabela comparativa abaixo, que as sintetiza e esclarece (Cauduro \& Rahde, 2002):

\section{Pensamento Moderno}

Paixão pelo novo e pela avant-garde; acredita no progresso, na qualidade superior do novo sobre o tradicional.

Procura contínua pelo único, pelo original, pelo singular, pelo novo, pelo inédito.

Artista visto como um criador solitário e dono absoluto das inovações inspiradas nas ciências (op art)

Singularizador através das suas descobertas.

Procura a universalidade.

Analógico e paradigmático (oposicional)

Rejeita o coletivo em favor do singular utópico, do narcisismo, do cartesiano, do ordenado, do racional, do econômico, do simples.

Acredita na história como progressão linear de eventos, na objetividade e progresso do mundo real.

Ética ascética, radical, absolutista.

Apolíneo, sacrificial, o ideal futuro.

Separação rígida entre eu e o outro.

Crença no indivíduo, no senhor consciente e indivisível, no ardoroso adepto de utopias racionalistas.

Cultura como uma hierarquia de valores, não aceita

manifestações kitsch.

Projetos de descoberta e invenção.

Transgressivo e utópico.

Linear, segregador, oposicional, progressista, hierárquico, purista, taxonômico.

Acredita nas aparentes verdades das

metanarrativas.

Funcional e monológico. Positivista.

Form follows function. Less is more. Ornament is

crime.Legibility comes first.

Elitista, científico, sistêmico, unitário, dogmático, universal.

Apriorístico, deducionista, homogêneo.

Identidade fixa e permanente.

Acredita em totalizações da realidade (global).

Imagem como descoberta de grandes verdades.

Imagem pela imagem, auto-suficiente, hermética.

Imagem lida segundo critérios formalistas e em relação à outras imagens.

Rejeita o contexto, quer pureza de interpretação.

Rejeita história, narrativas, simbolismos, símiles.

\section{Pensamento Pós-moderno}

Valoriza o ecletismo, combina diversos estilos numa mesma estrutura; bricolagem e hibridação de múltiplas diferenças, antigas ou novas.

Rejeita a busca do novo pelo novo apenas.

Artista como um facilitador de jogos técnicos de recombinações inspiradas na cultura (pop art).

Relativizador através das suas colagens.

Procura a multidimensionalidade.

Digital e sintagmático (combinatório)

Rejeita o individualismo em favor do coletivo, do anônimo, do participativo, do anárquico, do complexo.

Suspeita que só existam histórias-narrativas e equivalentes visões culturais de mundo.

Ética relativista, circunstancial, flexível.

Dionísico, prazeroso, o presente possível.

Continuação do eu no outro.

Opera com um sujeito contraditório, dividido e

submetido às pulsões do inconsciente.

Divisão entre cultura de elite e cultura

popular não faz mais sentido.

Processos de construção e simulação.

Combinatório e desconstrucionista.

Hipertextual, superpositor, conectivista, circular, horizontal, híbrido, reticular, incerto.

Acredita no prazer do jogo e das simulações.

Experimental e polissêmico. Relativista.

Form follows desire. Less is bore. Decoration is

art. Pleasure comes first.

Populista, vernacular, eclético, pluralista, relativista, local.

Hipotético, abducionista, heterogêneo.

Subjetividade móvel e mutante.

Aceita só contextualizações (local, regional).

Imagem como entretenimento, diversão.

Imagem como cultura e comunicação.

Imagem interpretada segundo a cultura e a história, e em relação a valores sociais.

Contextualiza e hibridiza as significações.

Cultiva alegorias, alusões, paródias, pastiches. 


\section{(e) compós}

Artistas são gênios, pessoas excepcionais.

Artistas são gente como a gente.

Reverencía o objeto artístico, único e aurático. Valoriza a produção e a difusão em massa de cópias.

\section{Considerações Finais}

Considerando as narrativas cinematográficas contemporâneas que tratam de supostos heróis, tipo de filme que têm se caracterizado como cinema espetáculo, já presente nas histórias em quadrinhos, vemos que utiliza uma linguagem com elementos simbólicos pertencentes a essa mídia cultural. A dimensão sociológica, psicanalítica, as complexidades humanas e sociais são evidenciadas, assim como a exploração do imaginário do espectador, numa multidimensionalidade iconográfica, que torna o espetáculo, subitamente, realidade, e, como afirma Morin, sobrepondo a imaginação à realidade e vice-versa, provocando a imersão do sujeito em alguma das muitas tramas que lhe são apresentadas. Mais ainda, as possibilidades das novas tecnologias torna-se banal realidade no imaginário narrativo cinematográfico. $\mathrm{O}$ herói mitológico em Batman assemelha-se ao herói das mitologias (Morin, 1989) que combate o mal, procurando a redenção do mundo, representado pela fictícia cidade de Gotham City.

Batman é um mito, mas deixa de ser fantasia para nutrir o imaginário cultural e social, numa visão simbiótica entre homem e herói, símbolo dos mais emblemáticos do universo dos quadrinhos, principalmente nos da contemporaneidade, com histórias bem engendradas e bem articuladas na construção mitopoiética. Como um dos grandes expoentes da mídia cultural, o cinema vem se apresentando como espetáculo de identificações projetivas do espectador com seus heróis, pois, diz ainda Morin (1989, p. 67) “o homem sempre projetou em imagens seus desejos e temores. E projetou sempre na sua própria imagem-em seu duplo - a necessidade de superar a si mesmo na vida e na morte. Este duplo é detentor de poderes mágicos latentes; qualquer duplo é um deus virtual”. Dessa forma justifica-se o sucesso da dupla pensonalidade e da permanência do herói mítico, como alimento do imaginário coletivo.

Retomamos aqui a afirmativa de Durand (1998) ao início dessas reflexões, quando refere que o Surrealismo é o resultado natural e reconhecido do Simbolismo. 
Esse é o universo de Batman e de alguns outros heróis das histórias em quadrinhos, que estão sendo agora figurados pelo cinema do contemporâneo. Envolto num mundo surreal, o herói é o símbolo de uma deidade humana, num ritual estético e iconográfico, ao resgatar e construir imaginários mítico culturais, que vêm acompanhando a jornada humana desde os mais remotos passados.

\section{Referências bibliográficas}

AUMONT, Jacques.A imagem. Campinas, SP: Papirus, 1995.

AVENS, Roberts. Imaginação é realidade. O nirvana ocidental em Jung, Hillman, Barfield e Cassirer. Petrópolis: Vozes, 1993.

BACHELARD, Gaston. O ar e os sonhos. São Paulo: Martins Fontes, 1990.

CAUDURO, FLAVIO V., e RAHDE, MARIA BEATRIZ F. Apontamentos para um Seminário de Pós-graduação sobre Imagem e Pós-modernidade, FAMECOS / PUCRS, 2002.

DURAND, Gilbert. O imaginário. Ensaio acerca das ciências e da filosofia da imagem. Rio de Janeiro: DIFEL, 1998.

ECO, Umberto. Apocalípticos e integrados. São Paulo: Perspectiva, 1970.

HARVEY, David. Condição pós-moderna. São Paulo: Loyola, 1992.

KELLNER, Douglas. A cultura da mídia. Estudos culturais: identidade e política entre moderno e pós-moderno. Baurú, SP: EDUSC, 2001.

LUZ, Rogério. Novas imagens: Efeitos e modelos. In: PARENTE, André. Image máquina. A era das tecnologias do virtual. Rio de Janeiro: Ed. 34, 1993, p. 49-55.

LYOTARD, Jean-François. La condicion postmoderna. Madrid, Cátedra, 1994.

MAFFESOLI, Michel. A contemplação do mundo. Porto Alegre: Artes e Ofícios, 1995. . No fundo das aparências. Petrópolis, RJ: Vozes, 1996.

. O eterno instante. O retorno do trágico nas sociedades pósmodernas. Lisboa: Piaget, 2001.

MALRIEU, Philippe. A construção do imaginário. Lisboa: Instituto Piaget, 1996.

MORIN, Edgar. As estrelas. Mito e sedução no cinema. Rio de Janeiro: José Olympio, 1989.

MOYA, Alvaro de. Shazam. São Paulo: perspectiva, 1970.

RUIZ, Castor Bartolomé. Os paradoxos do imaginário. São Leopoldo, RS: UNISINOS, 2003. 
THOMAS, Karin. Hasta hoy. Estilos de las artes plasticas en el siglo XX.

Barcelona: Ediciones del Serbal, 1994.

WEILER, Lucia. Da lógica do conhecimento para uma lógica do amor. Pistas para uma releitura filosófico-teológica do evangelho de João. In: ULLMANN, R.A. Consecratio Mundi.Festschrift em homenagem a Urbano Zilles. Porto Alegre: EDIPUCRS, 1998, p. 92-111. 